\title{
Molecular Cloning and Sequencing of Alkalophilic Cellulosimicrobium cellulans CKMX1 Xylanase Gene Isolated from Mushroom Compost and Characterization of the Gene Product
}

\author{
Abhishek Walia ${ }^{1 *}$, Preeti Mehta ${ }^{2}$, Shiwani Guleria ${ }^{3}$, Anjali Chauhan ${ }^{3}$ and C.K. Shirkot ${ }^{3}$ \\ ${ }^{I}$ Department of Microbiology; DAV University; Jalandhar, Punjab - India. ${ }^{2}$ DBT-IOC Centre for Bioenergy \\ Research, Indian Oil R\&D Centre, Haryana, India. ${ }^{3}$ Department of Basic Sciences (Microbiology Section); Dr. YS \\ Parmar University of Horticulture and Forestry; Nauni, Solan - India
}

\begin{abstract}
A xylanolytic bacterium was isolated from mushroom compost by using enrichment technique. Results from the metabolic fingerprinting, whole-cell fatty acids methyl ester analysis and 16S rDNA sequencing suggested the bacterium to be Cellulosimicrobium cellulans CKMX1. Due to the xylanolytic activity of this bacterium, isolation and characterization of the xylanase gene were attempted. A distinct fragment of about 1671 bp was successfully amplified using PCR and cloned into Escherichia coli DH5 . A BLAST search confirmed that the DNA sequence from the amplified fragment was endo-1, 4-beta-xylanase, which was a member of glycoside hydrolase family 11. It showed 98\% homology with Cellulosimicrobium sp. xylanase gene (Accession no. FJ859907.1) reported from the gut of Eisenia fetida in Korea. In silico physico-chemical characterization of amino acid sequence of xylanase showed an open reading frame encoding a 556 amino acid sequence with a molecular weight of $58 \mathrm{kDa}$ and theoretical isolectric point (pI) of 4.46 was computed using Expasy's ProtParam server. Secondary and homology based 3D structure of xylanase was analysed using SOPMA and Swiss-Prot software.
\end{abstract}

Key words: Cellulase free xylanase, Cellulosimicrobium cellulans, E.coli, Cloning, Gene

\section{INTRODUCTION}

Xylan is the major hemicellulosic constituent of hard and soft wood, and is the next most abundant renewable polysaccharide after cellulose. This complex heteropolysaccharide consists of a main chain of 1,4- $\beta$-D-xylose monomers and short chain branches consisting of O-acetyl, $\alpha$-Larabinofuranosyl and $\alpha$-D-glucuronyl residues. Xylanases and associated debranching enzymes produced by a variety of microorganisms including bacteria, yeast and filamentous fungi, bring about the hydrolysis of hemicelluloses
(Maheshwari et al. 2000). Xylanolytic enzymes are receiving increasing attention because of their potential application in pulp bleaching (Golugiri et al. 2012; Singh et al. 2013) and bioconversion of lignocelluloses into feedstocks and fuels (Kim et al. 2000). The xylan degrading system includes endo-1,4-xylanases $(1,4-\beta$-xylan xylanohydrolase; EC 3.2.1.8), which release long and short xylooligosaccharides, and other xylanases that attack only longer chains, and $\beta$-D-xylosidase $(1,4-\beta$ xylan xylohydrolase; EC 3.2.1.37), which remove D-xylose residues from short xylooligosaccharides (Saha 2003; Gomez et al. 2008).

*Author for correspondence: sunny_0999walia@yahoo.co.in 
Recent advances in molecular biology and genetic engineering in the last two decades have opened up the areas of application of gene cloning and recombinant DNA technology for the construction of genetically modified microbial strains with selected enzyme machinery. To ensure the commercial utilization of hemicellulosic residues in the pulp and paper industries, the production of higher xylanase yields at low capital cost is required. In this respect, isolation and cloning of the xylanase gene represents an essential step in the engineering of the most efficient microorganisms (Hernandez et al. 2008; Deesukon et al. 2011). Several reports describe the production, purification, partial characterization, molecular cloning, sequencing and expression of the alkaline xylanase gene from alkalophilic Bacillus sp. strain $\mathrm{C}-125$ in non-cellulase producing E.coli carrying a plasmid pCX311 (Liu et al. 2010; Verma and Satyanarayana, 2012; Driss et al. 2012). Such studies are essential to produce a more-efficient xylanase producer, which will allow improvement of paper quality (Walia et al. 2015). Furthermore, biochemical studies on xylanase-secreting and non-secreting microorganisms could lead to better understanding of the xylanase secretory process and the development of cloning strategies that would guarantee secretion of desired products. Various molecular and biotechnological aspects of xylanase producing microorganisms, such as the regulation of xylanase biosynthesis at the molecular level, and newer strategies, such as use of gene cloning, protein engineering, and sitedirected mutagenesis for obtaining xylanase with novel properties, have been described in detail by Kulkarni et al.(2003).

Thus, the aim of this work was to isolate, clone and sequencing of xylanase gene and physicochemical characterization of deduced amino acid sequence of xylanase gene by using Expasy's ProtParam server. Secondary and homology based 3D structure of xylanase was also analysed and compared with some other commercially important xylanases using significant improvement in protein secondary structure prediction by consensus prediction from multiple alignments (SOPMA) and Swiss-Prot software.

\section{MATERIAL AND METHODS}

\section{Strain isolation}

Alkalophilic Cellulosimicrobium cellulans CKMX1 was previously isolated from mushroom compost (Walia et al. 2013). Xylan degrading bacteria were isolated by the enrichment technique. The most predominant bacterial colonies capable of good growth on basal salt medium (BSM) with the following composition (g/L): $\mathrm{Na}_{2} \mathrm{HPO}_{4}, 6.0 ; \mathrm{KH}_{2} \mathrm{PO}_{4}, 3.0 ; \mathrm{NaCl}, 0.5$; $\mathrm{NH}_{4} \mathrm{Cl}, 1.0,1 \mathrm{M} \mathrm{MgSO}_{4}(2 \mathrm{~mL})$ and $1 \mathrm{M} \mathrm{CaCl}_{2}$ $(0.1 \mathrm{~mL})$ were picked and purified. The bacterial culture was grown and maintained in BSM, $\mathrm{pH}$ 8.0, containing $0.5 \%$ xylan. The bacterial culture was maintained in $30 \%$ glycerol at $-20^{\circ} \mathrm{C}$.

\section{Identification of bacteria}

The bacterium was identified using colony morphology observation, biochemical tests, whole-cell fatty acid methyl ester analysis and $16 \mathrm{~S}$ rDNA sequencing.

\section{Bacterial DNA extraction}

Bacterial isolate was grown in nutrient broth at $35^{\circ} \mathrm{C}$ overnight and the cells were harvested by centrifugation at $5,000 \times \mathrm{g}$ for $5 \mathrm{~min}$. DNA was isolated from these cells by using Real genomic DNA extraction kit (Taiwan), which was suspended in $100 \mu \mathrm{L}$ of elution buffer and quantified on $1 \%$ agarose gel. The total genomic DNA was kept at $-20^{\circ} \mathrm{C}$ before use (Sambrook and Russel 2001).

\section{PCR amplification of 16S rDNA and sequence determination}

Species level identification of strain was conducted by $16 \mathrm{~S}$ rDNA sequence comparison. PCR reaction was carried out in $20 \mu \mathrm{L}$ reaction containing $~ 50 \mathrm{ng}$ of template DNA, 20 pmoles of each primer fC1 (5'GCAAGTCGAGCGGACAGATGGGAGC-3')

and reverse primer $\mathrm{rC}^{2}$ (5'AACTCTCGTGGTGTGACG GGCGGTG-3'), $0.2 \mathrm{mM}$ dNTPs and $1 \mathrm{U}$ Taq polymerase (Genei Bangalore) in $1 \mathrm{x}$ PCR buffer. Reaction were cycled 35 times as $94^{\circ} \mathrm{C}$ for $30 \mathrm{~s}, 58^{\circ} \mathrm{C}$ for $30 \mathrm{~s}$, $72^{\circ} \mathrm{C}$ for $1 \mathrm{~min} 30 \mathrm{~s}$, followed by final extension at $72^{\circ} \mathrm{C}$ for $10 \mathrm{~min}$. The PCR products were analyzed on $1 \%$ agarose gel in $1 \mathrm{x}$ TAE buffer, run at $100 \mathrm{~V}$ for $1 \mathrm{~h}$. Gels were stained with ethidium bromide and photographed. Amplified PCR products were eluted from the gel using gel extraction kit (Real genomic Hi Yield TM Gel/PCR DNA Extraction Kit), eluted fragment was then sequenced (Xcleris, India) using PCR primers. 


\section{Primers for cloning of xylanase gene}

PCR Primers to amplify the xylanase gene were designed based on the endo-1,4-beta-xylanase gene sequences from different Cellulosimicrobium sp. DNA sequences of xylanases were obtained from GenBank (www.ncbi.nlm.nih.gov) and were aligned using ClustalW (Larkin et al. 2007) and CLC sequence viewer (www.clcbio.com). Conserved regions were detected.

i) Primers for cloning and sequencing of partial xylanase gene

Following set of primers were designed on the basis of gene sequences of earlier known xylanases submitted in NCBI database:

Primer set 1:

These primers were designed using known consensus sequences of xylanase:

Forward XylF: 5'-cgtcggcttcgcgctcgaccc-3' (21 mer)

Reverse XylR: 5'-cggtgatgcgcacgtccacgcc-3' (22 mer)

ii) Primers for cloning and sequencing of complete xylanase gene

Primer set 1:

These primers were designed from the closest match of known partial sequence of xylanase CKMX1:

Forward

XylCompF:

$$
5
$$

atgaccaggaccatctggagacgacc-3' (26 mer)

Reverse XylCompR:

tcaggcgacctcgcaggcggcaccgtcg-3' (28 mer)

The above primers were custom synthesized and supplied in lyophilized form by ITC Promega. Primers were regenerated by suspending in autoclaved double distilled water to make $1.0 \mathrm{~mL}$ of $1 \mathrm{pM}$ primer before use.

\section{Xylanase gene isolation}

PCR was performed using the genomic DNA isolated from the bacterium as a template. PCR reaction were cycled 30 times as denaturation was $94^{\circ} \mathrm{C}$ for $45 \mathrm{~s}$, annealing was $45^{\circ} \mathrm{C}$ for $1 \mathrm{~min}$ and extension was $72^{\circ} \mathrm{C}$ for $2 \mathrm{~min}$ followed by final extension at $72^{\circ} \mathrm{C}$ for $10 \mathrm{~min}$.

\section{Cloning and transformation}

Purified PCR products (amplicons) was ligated into pGEM-T easy cloning vector as per manufacturer's instructions (pGMET- clone kit, Promega) and transformed into E. coli DH5 $\alpha$ competent cells using the heatshock method. Successful transformants were selected using blue/white screening. Plasmids were extracted using a plasmid extraction kit (Axygen Prep ${ }^{\mathrm{TM}}$ Plasmid Mini prep Kit), according to manufacturer's instruction from the culture with positive colony PCR results verified by restriction digest, and was sent for sequencing by the commercial sequencing facility (Xcleris lab).

\section{Plate assay for screening recombinants}

The recombinants containing desired PCR product inserts were screened for the expression of xylanase activity by the Congo-red assay described by Teather and Wood (1982). The recombinant $E$. coli clones containing the recombinants were overlaid with $0.5 \%$ oat-spelt xylan, dissolved in solid LB and then incubated at $37^{\circ} \mathrm{C}$ overnight. Then, the plates were stained with $1 \%$ Congo-red for $30 \mathrm{~min}$ and destained with $1 \mathrm{M}$ $\mathrm{NaCl}$. Positive clones were identified by a zone of clearance around xylanase-expressing clones truncated.

Sequencing and phylogenetic analysis of xylanase gene of $C$. cellulans CKMX1

The sequence was aligned with corresponding sequences of 16S rRNA from the database using BLAST from the website http://www.ncbi.nlm.nih.gov/blast (Altschul et al.1997). Multiple alignments were generated by the MULTALIN program from the website: http://prodes.toulouse.inra.fr/multialin/multialin.ht $\mathrm{ml}$ (Corpet 1998). The phylogenetic trees were constructed after truncating the sequences to the length of shortest sequence in a given alignment data by neighbor-joining algorithm using PHYLIP Package (Felsenstein et al. 1993). The stability among clades of a phylogenetic tree was assessed by taking 1000 replicates of the data set and was analyzed using the programs SEQBOOT, DNADIST, NEIGHBOR and CONSENSE of the PHYLIP package. Tree was viewed with the help of TreeView from the website http://taxonomy.zoology.gla.ac.uk/rod/treeview.ht ml (Page 1996).

\section{Physico-chemical characterization of amino acid sequence of xylanase}

Amino acid sequence of xylanase gene of $C$. cellulans CKMX1 was deduced by using xylanase gene sequence of strain CKMX1 and translates into protein sequence by expasy protein software. Theoretical isoelectric point $(\mathrm{pI})$, molecular weight, total number of positive and negative 
residues, instability index (Guruprasad et al. 1990), aliphatic index (Ikai 1980) were computed using the Expasy's ProtParam server (Gasteiger et al. 2005) (http://us.expasy.org/tools/ protparam.html). Amino acid composition of the protein sequences could reveal their nature; hence, amino acid composition was also computed.

\section{Secondary structure prediction}

SOPMA was employed for calculating the secondary structural features of the selected target protein sequences considered for this study (Geourjon and Deleage 1995).

\section{Homology-based structural model of xylanase}

Homology-based structural model of xylanase from $C$. cellulans CKMX1 was built using SWISS-MODEL server (http://swissmodel.expasy.org/). Exo-beta-1, 4glucanase from Cellulomonas fimi (PDB ID: 3CUG, $69.16 \%$ sequence identity) was used as template to build the structural model of xylanase. The model was visualised using PyMOL (Delano 2002) The PyMOL Molecular Graphics System (2002) found online (http://pymol.org)].

\section{RESULTS}

\section{Isolation and identification}

Xylanolytic bacteria was previously isolated from the enriched culture on basal salt media (BSM) containing xylan as the sole carbon source and identified as $C$. cellulans CKMX1 according to morphological, biochemical, whole-cell fatty acid methyl ester analysis and 16S rDNA sequence (Walia et al. 2013; 2014).

\section{Phylogenetic analysis of isolate CKMX1 according to $16 \mathrm{~S}$ rDNA sequence}

Universal primers were used successfully to amplify 16S rDNA from bacterial isolate CKMX1, yielding an amplicon of the expected size, i.e., $\sim 1136$ bp. The sequence of 16S rDNA from CKMX1 was then analyzed using BLASTn analysis (http://www.ncbi.nlm.nih.gov/blast) and was found to have $97 \%$ homology with several $C$. cellulans strains reported earlier. The 16S rDNA sequence of CKMX1 was also compared with the corresponding sequences of eight different Cellulosimicrobium sp. reported earlier. Sequence analysis revealed that CKMX1 belonged to $C$. cellulans strain CKMX1 as it showed maximum homology (97\%) with C. cellulans strain AMP-11 (Accession no. HM104377).

To trace out the evolutionary patterns of the test isolate and to determine the relationship with other selected sequences at NCBI, a phylogenetic tree was also constructed using the neighbour-joining (J) method of mathematical averages among $16 \mathrm{~S}$ rDNA sequence of CKMX1 and the corresponding sequence of eight different Cellulosimicrobium sp. strain CKMX1 was united with quite high statistical support by the bootstrap estimates for 1,000 replications. The resulting phylogenetic tree also verified CKMX1 as $C$. cellulans as it clustered closely with $C$. cellulans with high $(80 \%)$ boot strap value. The 16S rDNA sequence of the strain has been deposited in the GenBank database under accession number JN135476.

Detection and isolation of xylanase gene from genomic DNA of $C$. cellulans CKMX1 using specific primer based PCR method

Xylanase gene specific primers were designed for the isolation of partial xylanase i.e., $\mathrm{XylF}$ and $\mathrm{XylR}$, as mentioned in the materials and methods section, were used for the detection and amplification of partial xylanase gene from $C$. cellulans CKMX1. PCR reaction resulted in the amplification of $\sim 564 \mathrm{bp}$ fragment as expected for partial xylanase gene. The amplified fragment was then excised from the gel and was used for cloning into pGEM-T easy vector.

DNA sequencing and cloning of PCR product into pGEM-T easy vector system

The purified PCR product was ligated to pGEM-t easy vector and finally transformed to competent E. coli (DH5 $)$ cells. Positive clone containing insert was identified using colony PCR. Plasmid was then isolated from the selected positive colony and was sequenced. Sequence of 564 bp corresponding to partial xylanase gene of CKMX1 was obtained. The partial xylanase gene sequence of the strain was deposited in the GenBank database under accession number HF546135.

Amplificantion and sequencing of complete xylanase gene from $C$. cellulans CKMX1

After obtaining the partial sequence of xylanase gene from $C$. cellulans CKMX1, primers were designed as described in the material and methods section based on the known partial sequence of xylanase CKMX1. An expected amplification 
product of $\sim 1671$ bp was obtained in PCR amplification using designed primers (Fig. 1).

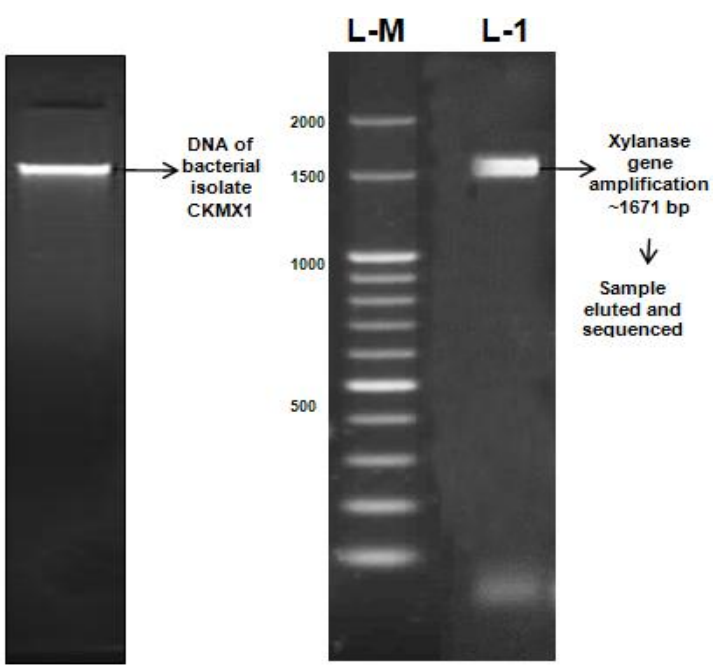

Figure 1 - Agarose gel electrophoresis showing the isolation of DNA and amplification of complete xylanase gene from $C$. cellulans CKMX1. Lane M: 100 bp Marker, Lane 1: Showing $~ 1671$ bp amplification.

PCR product was then cloned to pGEM-T easy vector system and transformed to competent $E$. coli $(\mathrm{DH} 5 \alpha)$ cells. Clones containing insert was then identified using colony PCR. Plasmid was then isolated from selected positive colony and was sequenced. Sequence of $1671 \mathrm{bp}$ corresponding to complete xylanase gene of CKMX1 was obtained.

\section{Sequence analysis of complete xylanase gene of C. cellulans CKMX1}

Sequence of complete xylanase gene of $C$. cellulans CKMX1 was analysed with corresponding sequences of nineteen different sequences of xylanase gene from Cellulosimicrobium sp. reported earlier. Sequence analysis revealed that xylanase gene of $C$. cellulans CKMX1 showed maximum homology (98\%) with xylanase gene of Cellulosimicrobium sp. (Accession no. FJ859907.1) reported from the gut of Eisenia fetida in Korea, followed by $75.6 \%$ homology with Streptomyces rameus strain L2001 (Accession no. KC011007).

C. cellulans CKMX1 was united with quite high statistical support by the bootstrap method and value inferred higher than $40 \%$ are only presented in Figure 2. Phylogenetic tree based on complete xylanase sequences (Fig. 2) validated that the xylanase gene of $C$. cellulans CKMX1 clustered closely with xylanase gene of other reported isolates of Cellulosimicrobium sp. with high boot strap value $(100 \%)$. The complete xylanase gene sequence of the strain has been deposited in the GenBank database under accession number HG425182. Multiple sequence alignment of xylanase gene of strain CKMX1 with closely related strain HY-13 was done by ClustalW alignment software. Nucleotide sequence of CKMX1 was then used to deduce the amino acid sequence of the xylanase protein using expasy protein translation tool (http://us.expasy.org/ tools.html). Amino acid sequence corresponding to xylanase protein from CKMX1 was also aligned with the corresponding amino acid sequence from C. Cellulans strain HY-13 reported from the gut of E. fetida in Korea.

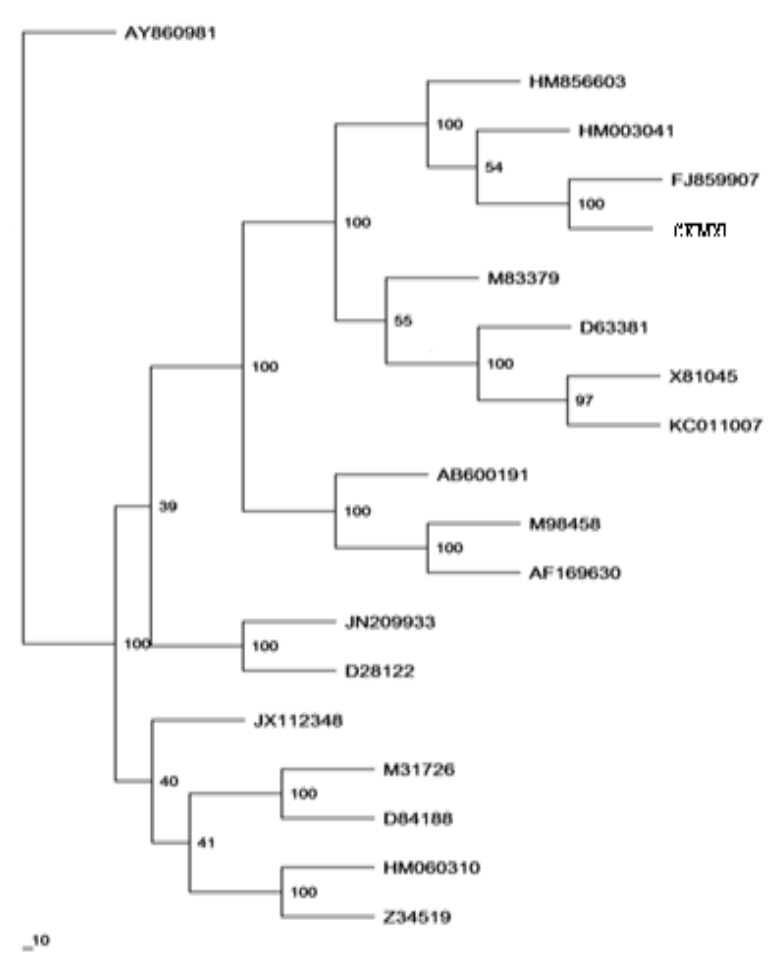

Figure 2 - Neighbour-joining phylogenetic tree based on complete xylanase gene sequence data of $C$. cellulans CKMX1 and related strains. Isolate used in the study is in boldface.

\section{Physico-chemical characterization of amino acid sequence of xylanase}

Theoretical isoelectric point (pI), molecular weight, total number of positive and negative residues, instability index, and aliphatic index were computed using the Expasy's ProtParam server (http://us.expasy.org/tools/protparam.html). 
Amino acid composition of the protein sequences could reveal their nature; hence, amino acid composition was also computed (Table 1).

Maximum percentage composition of alanine was $15.1 \%$, followed by threonine $11.2 \%$, glycine $10.4 \%$, valine $7.9 \%$ and so on. The amino acid composition of xylanase polypeptide showed that it contained 63 negatively charged residues (Asp+Glu) and 37 positively charged residues (Arg+Lys). The xylanases from different microorganisms showed significant similarity when theoretical protein parameters were compared (Table 2). The pI values of all protein sequences were in the range of 4.32-9.57, indicating that all considered xylanase sequences were acidic, except C.flavigena XIB (9.57), C. flavigena DSM 20109 (8.94), Cellvibrio gilvus ATCC 13127 (8.70) and Bacillus subtilis (9.18), Pedobacter saltans DSM 12145 (9.16). The xylanase of $C$. cellulans CKMX1 had the highest pI value of 4.66 , which showed the xylanase sequence was acidic.

\begin{tabular}{llcc}
\hline \multicolumn{2}{c}{ Amino acid } & No. & Percentage composition (\%) \\
\hline Ala & (A) & 84 & 15.1 \\
Arg & (R) & 28 & 5.0 \\
Asn & (N) & 12 & 2.2 \\
Asp & (D) & 42 & 7.6 \\
Cys & (C) & 5 & 0.9 \\
Gln & (Q) & 23 & 4.1 \\
Glu & (E) & 21 & 3.8 \\
Gly & (G) & 58 & 10.4 \\
His & (H) & 10 & 1.8 \\
Ile & (I) & 18 & 3.2 \\
Leu & (L) & 34 & 6.1 \\
Lys & (K) & 9 & 1.6 \\
Met & (M) & 4 & 0.7 \\
Phe & (F) & 20 & 3.6 \\
Pro & (P) & 24 & 4.3 \\
Ser & (S) & 29 & 5.2 \\
Thr & (T) & 62 & 11.2 \\
Trp & (W) & 15 & 2.7 \\
Tyr & (Y) & 14 & 2.5 \\
Val & (V) & 44 & 7.9 \\
Pyl & (O) & 0 & 0.0 \\
Sec & (U) & 0 & 0.0 \\
\hline
\end{tabular}

Table 1 - Deduced amino acid composition of xylanase of $C$. cellulans CKMX1.

Table 2 - Theoretical protein parameters of few xylanases calculated using bioinformatics tools.

\begin{tabular}{|c|c|c|c|c|c|c|c|}
\hline Organism & $\begin{array}{l}\text { Molecular } \\
\text { weight (Da) }\end{array}$ & $\begin{array}{l}\text { Amino } \\
\text { acid No. }\end{array}$ & $p \mathbf{I}$ & $\begin{array}{l}\text { No. of } \\
\text { charged } \\
\text { residues }\end{array}$ & $\begin{array}{l}\text { Total no. } \\
\text { of atoms }\end{array}$ & $\begin{array}{l}\text { Instability } \\
\text { index }\end{array}$ & $\begin{array}{l}\text { Aliphatic } \\
\text { index }\end{array}$ \\
\hline $\begin{array}{l}\text { Cellulosimicrobium cellulans } \\
\text { CKMX1 }\end{array}$ & 58489.6 & 556 & 4.66 & 100 & 8085 & 22.89 & 74.53 \\
\hline Cellulosimicrobium sp. HY-13 & 58296.3 & 556 & 4.59 & 101 & 8052 & 25.17 & 75.23 \\
\hline Cellulosimicrobium sp. HY-12 & 42925.1 & 395 & 5.59 & 77 & 5984 & 38.99 & 77.65 \\
\hline Cellulomonas flavigena & 26314.5 & 261 & 5.21 & 23 & 3506 & 26.50 & 34.71 \\
\hline Cellulomonas flavigena XIB & 35110.1 & 332 & 9.57 & 31 & 4773 & 31.17 & 47.59 \\
\hline $\begin{array}{l}\text { Cellulomonas flavigena } \\
20109\end{array}$ & 50310.5 & 472 & 8.94 & 62 & 6886 & 33.65 & 56.14 \\
\hline Cellulomonas fimi ATCC 484 & 141665.2 & 1350 & 4.32 & 260 & 19715 & 27.78 & 85.79 \\
\hline Cellvibrio gilvus ATCC 13127 & 49781.9 & 469 & 8.70 & 66 & 6831 & 27.32 & 60.43 \\
\hline Bacillus sp. A & 45294.3 & 396 & 4.65 & 106 & 6267 & 32.69 & 78.31 \\
\hline Bacillus subtilis & 22409.4 & 206 & 9.18 & 24 & 3056 & 16.14 & 52.52 \\
\hline Geobacillus stearothermophilus & 70596.5 & 620 & 4.96 & 149 & 9814 & 37.08 & 77.23 \\
\hline Paenibacillus polymyxa E681 & 67509.2 & 631 & 5.95 & 87 & 9346 & 17.43 & 73.76 \\
\hline Pedobacter saltans DSM 12145 & 33580.5 & 306 & 9.16 & 57 & 4745 & 37.78 & 95.33 \\
\hline $\begin{array}{l}\text { Granulicella } \\
\text { MP5ACTX8 }\end{array}$ & 34016.8 & 314 & 6.63 & 56 & 4795 & 42.29 & 90.38 \\
\hline
\end{tabular}

Instability index showed that all the considered sequences were classified as stable with values ranging from 16.14 to 38.99 , except Granulicella mallensis MP5ACTX8 (42.29). The xylanase sequence of $C$. cellulans CKMX1 showed instability index (22.89) as a value $>40$ indicated a stable protein. Aliphatic index for the xylanase sequences ranged from 34.71-95.33. The very high aliphatic index of all xylanase sequences indicated that these xylanases could be stable for a wide 
temperature range, including the xylanase sequence of $C$. cellulans CKMX1, which showed 74.53 aliphatic index.

\section{Secondary structure prediction}

Significant improvement in protein secondary structure prediction by consensus prediction from multiple alignments (SOPMA) was employed for calculating the secondary structural features of the selected target protein sequences considered for this study. The secondary structure indicates whether a given amino acid lies in a helix, strand or coil. Secondary structure features as predicted using SOPMA are represented in Table 3. The results revealed that random coils dominated among secondary structure elements, followed by alpha helix, extended strand and beta turn in $C$. cellulans CKMX1.
Table 3 - Calculated secondary structure elements of $C$. cellulans CKMX1.

\begin{tabular}{lc}
\hline Secondary structure & C. cellulans CKMX1 (\%) \\
\hline Alpha helix $(\mathrm{Hh})$ & 27.70 \\
$3_{10}$ helix $(\mathrm{Gg})$ & 0.00 \\
Pi helix (Ii) & 0.00 \\
Beta bridge $(\mathrm{Bb})$ & 0.00 \\
Extended strand $(\mathrm{Ee})$ & 19.24 \\
Beta turn $(\mathrm{Tt})$ & 7.19 \\
Bend region $(\mathrm{Ss})$ & 0.00 \\
Random coil $(\mathrm{Cc})$ & 45.86 \\
Ambigous states & 0.00 \\
Other states & 0.00 \\
\hline
\end{tabular}

\section{Homology based 3D structure prediction}

The molecular model of the endo-1,4- $\beta$ xylanase is described as consisting of an alpha helix and several beta pleated sheets with a compact structure and is shown in Figure 3.

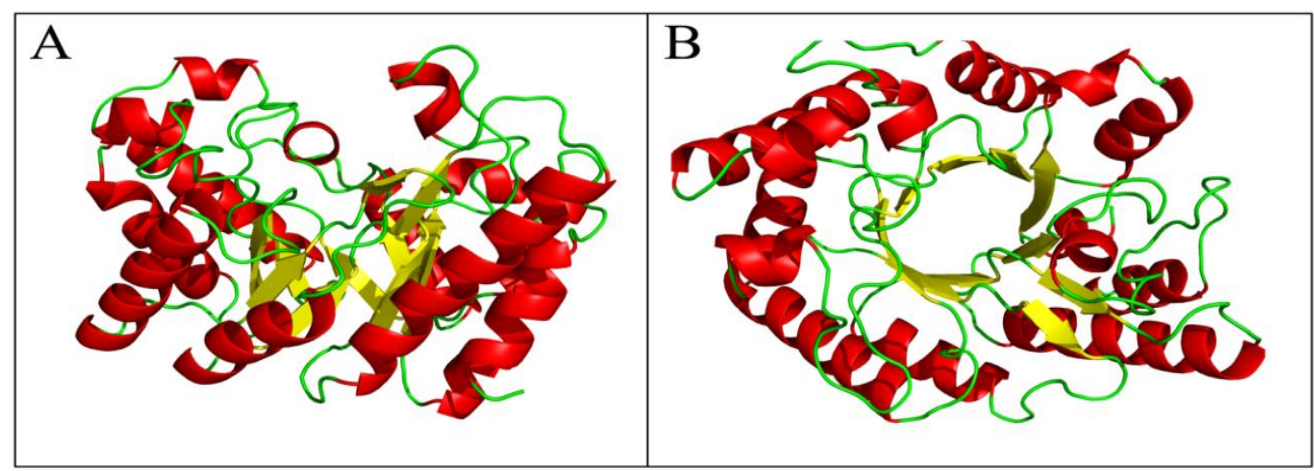

Figure 3 - Homology based 3D structure of xylanase proteins by using Swiss-Prot model A) Side view B) Top view.

\section{DISCUSSION}

Several recombinant xylanases from bacteria, yeast and fungi have been cloned and expressed in $E$. coli by construction of genomic libraries, followed by expression cloning. In this study, a highly xylanolytic C.cellulans CKMX1 was isolated from mushroom compost. Cellulomonas sp. is known to produce and secrete a variety of hydrolytic enzymes, and thus can utilize various complex carbohydrates in their natural habitats such as soil. Xylanases are produced in various amounts by bacteria and filamentous fungi to degrade xylan as a source of energy and have potential application in a wide range of industrial processes (Kulkarni et al. 2003; Keshwani and Cheng 2009). Xylanases encoding genes from
Cellulomonas species have been cloned and sequenced (Bhalero et al. 1990). Multiple xylanases may be produced by the organisms to enhance the utilization of xylan (Wong et al. 1988).

In the present study, C. cellulans CKMX1 had unique ability to produce cellulase-free xylanase (Walia et al. 2012; Walia et al. 2013 and 2014). The results also showed the xylan hydrolysis by endoxylanases $\quad(1,4-\beta-D-x y l a n$ xylanohydrolase E.C.3.2.1.8). Therefore, C. cellulans CKMX1 isolated from mushroom compost was selected for further identification of xylanse encoding gene responsible for xylanase production. The PCR results obtained showed that the $C$. cellulans CKMX1 exhibited a band of $1671 \mathrm{bp}$, corresponding to a fragment of xylanase encoding 
gene (Fig. 1). The nucleotide sequence of $1671 \mathrm{bp}$ amplicon shared $98 \%$ homology to xylanase gene of Cellulosimicrobium sp. HY-13 endo-beta-1,4xylanase (xylK-1) gene, (Accession no. FJ859907), thus confirming the isolation of xylanase gene from C. cellulans CKMX1 (Fig. 1). A positive clone, indicating that the clone contained an insert of $1671 \mathrm{bp}$ in size with a $58 \%$ $\mathrm{G}+\mathrm{C}$ content, in conformity with the high $\mathrm{G}+\mathrm{C}$ levels was found in nucleotide sequences from other Cellulosimicrobium sp., e.g., endo-beta-1, 4xylanase gene from Cellulosimicrobium sp. HY-13 (Kim et al. 2009). The conserved domain search of the xylanases gene across the Cellulosimicrobium sp. and other bacterial species indicates the significance of enzyme in xylan hydrolysis. The mature protein consisted of amino acids 556 with calculated molecular weight of $58 \mathrm{KDa}$. To-date, many xylanases genes have been cloned from different microorganisms, including Actiomadura sp. S14 (Thayat et al. 2011), Paenibacillus sp. 1211 (Zhao et al. 2011) and Streptomyces sp. S27 (Li et al. 2009). However, this study was to clone a xylanase gene from $C$. cellulans CKMX1 and a very little information was available regarding cellulase-free xylanases from $C$. cellulans CKMX1. Further, the work regarding hyperxylanolytic production could be done in vivo. Amino acid composition determines the fundamental properties of the enzyme (Arora et al. 2009). The amino acid composition of xylanase sequences is represented in Table 1 . The $\mathrm{pI}$ values of all protein sequences were in the range of 4.329.57, indicating that all considered xylanase sequences were acidic except $C$. flavigena XIB (9.57), C. flavigena DSM 20109 (8.94), Cellvibrio gilvus ATCC 13127 (8.70), B. subtilis (9.18) and Pedobacter saltans DSM 12145 (9.16). The xylanase enzyme of $C$. cellulans CKMX1 had the pI value of 4.66 which showed that the xylanase sequence was acidic (Arora et al. 2009). The calculated isoelectric point (pI) will be useful because at pI, solubility is least and mobility in an electro focusing system is zero. The instability index, which gives clue about the stability of a protein in vitro, can be calculated using Expasy's ProtParam server (Geourjon and Deleage 1995). All the considered sequences were classified as stable with values ranging from 16.14 to 38.99 , except Granulicella mallensis MP5ACTX8 (42.29). The xylanase sequence of $C$. cellulans CKMX1 (22.89) indicated a stable protein (Table 2).
The aliphatic index (AI), which is defined as the relative volume of a protein occupied by aliphatic side chains, is regarded as a positive factor for the increase of thermal stability of globular proteins. It can be calculated by using equation, i.e., Aliphatic index $=\mathrm{X}(\mathrm{Ala})+\mathrm{a} * \mathrm{X}(\mathrm{Val})+\mathrm{b} * \mathrm{X}(\mathrm{Leu}))+$ $b^{*} \mathrm{X}(\mathrm{Ile})$ and Expasy's ProtParam server (Gasteiger et al. 2005). Aliphatic index for the xylanase sequences ranged from 34.71-95.33 (Table 2). The very high aliphatic index of all xylanase sequences indicated that these xylanases could be stable for a wide temperature range, including the xylanase sequence of $C$. cellulans CKMX1, which showed 74.53 aliphatic index (Arora et al. 2009). The secondary structure indicates whether a given amino acid lies in a helix, strand or coil. Secondary structure features as predicted using SOPMA are represented in Table 3. The results revealed that random coils dominated among the secondary structure elements, followed by alpha helix, extended strand and beta turn. The molecular model of the endo1,4- $\beta$ xylanase is described as consisting of an alpha helix and several beta pleated sheets with a compact structure and is shown in Figure 3.

This is the first report describing cellulase-free xylanase by $C$. cellulans CKMX1 isolated from mushroom compost. Coupled with the small compact structure of the enzyme allowed it to degrade the xylan without damaging the cellulose fibres in the cellulose-hemicellulose matrix. This enzyme was also used in pulp and paper industry and showed positive results.

\section{CONCLUSION}

An endo-1,4-beta-xylanase gene from actinomycetes was isolated and characterized. The bacterium was identified as $C$. cellulans CKMX1 based on the morphological, biochemical characterisation, whole cell fatty acid methyl ester analysis and $16 \mathrm{~S}$ rDNA sequence. The xylanase gene of this bacterium, however, showed higher similarity to Cellulosimicrobium sp. deposited in the NCBI database.

\section{ACKNOWLEDGMENTS}

We thank Department of Science and Technology, Ministry of Science and Technology, Govt. of India, for providing contingency grant through Inspire Fellowship. 


\section{REFERENCES}

Altschul SF, Thomas LM, Alejandro AS, Jinghui Z, Zheng Z, Webb M, et al. Gapped BLAST and PSIBLAST: a new generation of protein database search programs. Nucleic Acids Res. 1997; 25: 33893402 .

Arora N, Banerjee AK, Mutyala S, Murty US. Comparative characterization of commercially important xylanase enzymes. Bioinformation. 2009; 3(10): 446-453.

Bhalerao J, Patki AH, Bhave M, Khurana I, Deobagkar DN. Molecular cloning and expression of a xylanase gene from Cellulomonas sp. into Escherichia coli. Appl Microbiol Biotechnol. 1990; 34: 71-76.

Corpet F. Multiple sequence alignment with hierarchial clustering. Nucleic Acids Res. 1988; 16: 1088110890.

Deesukon W, Nishimurab Y, Haradab N, Sakamotob T, Wasana S. Purification, characterization and gene cloning of two forms of a thermostable endo-xylanase from Streptomyces sp. SWU10. Proc Biochem. 2011; 46: 2255-2262.

DeLano WL. "The PyMOL Molecular Graphics System." DeLano Scientific LLC, San Carlos, CA, USA. http://www.pymol.org. 2002.

Driss D, Bhiri F, Ghorbel R, Chaabouni SE. Cloning and constitutive expression of His-tagged xylanase GH 11 from Penicillium occitanis Pol6 in Pichia pastoris X33: purification and characterization. Protein Express Purif. 2012; 83: 8-14.

Felsenstein J. PHYLIP (Phylogeny Inference Package) version 3.5c. Department of Genetics, University of Washington Seattle. 1993.

Gasteiger E, Hoogland C, Gattiker A, Duvaud S, Wilkins MR, Appel RD, et al. Protein identification and analysis tools on the ExPASy server. In: Walker JM. The proteomics protocols handbook. Human Press; 2005. pp. 571-607.

Geourjon C, Deleage G. SOPMA: significant improvements in protein secondary structure prediction by consensus prediction from multiple alignments. Comput Appl Biosci. 1995; 11(6): 681684.

Goluguri BR, Thulluri C, Cherupally M, Nidadavolu N, Achuthananda D, Mangamuri LN, et al. Potential of thermo and alkali stable xylanases from Thielaviopsis basicola (MTCC-1467) in biobleaching of wood Kraft pulp. Appl Biochem Biotechnol. 2012; 167: 2369-2380.

Gomez LD, Steele-King CG, McQueen-Mason SJ. Sustainable liquid biofuels from biomass: the writing's on the walls. The New Phytologist. 2008; 178(3): 473-485.
Guruprasad K, Reddy BV, Pandit MW. Correlation between stability of a protein and its dipeptide composition: a novel approach for predicting in vivo stability of a protein from its primary sequence. Protein Eng. 1990; 4(2): 155-161.

Hernández A, López JC, Arenas M, Santamaría R, Díaz M, Fernández-Abalos $\mathrm{J}$ M, et al. Xylan-binding xylanase $\mathrm{Xyl} 30$ from Streptomyces avermitilis: cloning, characterization, and overproduction in solid-state fermentation. Intern Microbiol. 2008; 11: 133-141.

Ikai AJ. Thermostability and aliphatic index of globular proteins. J Biochem. 1980; 88(6): 1895-1898.

Jeong KJ, Lee PC, Park IY, Kim MS, Kim SC. Molecular cloning and characterization of an endoxylanase gene of Bacillus sp. in Escherichia coli. Enzyme Microb Technol. 1998; 22: 599-605.

Keshwani DR, Cheng JJ. Switchgrass for bioethanol and other value-added applications: a review. Bioresour Technol. 2009; 100: 1515-1523.

Kim DY, Han MK, Park DS, Lee JS, Oh HW, Shin DH, et al. Novel GH10 xylanase, with a fibronectin type 3 domain, from Cellulosimicrobium sp. strain HY-13, a bacterium in the gut of Eisenia fetida. Appl Environ Microbiol. 2009; 75(22): 7275-7279.

Kim JH, Kim SC, Nam SW. Constitutive overexpression of the endoxylanase gene in Bacillus subtilis. J Microbiol Biotechnol. 2000; 10: 551-553.

Kulkarni N, Shendye A, Rao M. Molecular and biotechnological aspects of xylanases. FEMS Microbiol Rev. 2003; 23: 411-456.

Larkin MA, Blackshields G, Brown NP, Chenna R, McGettigan PA, McWilliam H, et al. ClustalW and ClustalX version 2. Bioinformatics. 2007; 23: $2947-$ 2948.

Li N, Shi P, Yang P, Wang Y, Luo H, Bai Y, et al. Cloning, expression, and characterization of a new Streptomyces sp. S27 xylanase for which xylobiose is the main hydrolysis product. Appl Biochem Biotechnol. 2009; 159: 521-531.

Liu Wanli, Shi Pengjun, Chen Qiang, Yang Peilong, Wang Guozeng, Wang Yaru, et al. Gene cloning, overexpression, and characterization of a xylanase from Penicillium sp. CGMCC 1669. Appl Biochem Biotechnol. 2010: 162: 1-12.

Maheshwari R, Bharadwaj G, Bhat MK. Thermophilic fungi: their physiology and enzymes. Microbiol Mol Biol Rev. 2000; 64: 461-488.

Page RDM. TREEVIEW: An application to display phylogenetic trees on personal computers. Comput Appl Biosci. 1996; 12: 357-358.

Saha BC. Hemicellulose bioconversion. J Indust Microbiol Biotechnol. 2003; 30: 279-291.

Sambrook J, Russel DW. Molecular cloning: a laboratory manual. Cold spring Harbor Laboratory, New York. 2001. 
Singh V, Pandey VC, Agrawal S. Potential of Laceyella sacchari strain B42 crude xylanase in biobleaching of kraft pulp. Afr J Biotechnol. 2013; 12(6): 570-579.

Teather RM, Wood PJ. Use of Congo redpolysaccharide interactions in enumeration and characterization of cellulolytic bacteria from the bovine rumen. Appl Environ Microbiol. 1982; 43: 777-780.

Thayat S, Peechapack S, Kenji M, Fusako K, Kosum C. Cloning of a thermostable xylanase from Actinomadura sp. S14 and its expression in Escherichia coli and Pichia pastoris. J Biosci Bioeng. 2011; 111: 528-536.

Verma D, Satyanarayana T. Molecular approaches for ameliorating microbial xylanases. Bioresource Technol. 2012; 17: 360-367.

Walia A, Mehta P, Chauhan A, Shirkot CK. Production of alkalophilic xylanases by Paenibacillus polymyxa CKWX1 isolated from decomposing wood. Proc Natl Acad Sci India Sect B Biol Sci. 2012; 83(2): 215-223.

Walia A, Mehta P, Chauhan A, Shirkot CK. Optimization of cellulase-free xylanase production by alkalophilic Cellulosimicrobium sp. CKMX1 in solidstate fermentation of apple pomace using central composite design and response surface methodology. Ann Microbiol. 2013; 63: 187-198.

Walia A, Mehta P, Chauhan A, Kulshrestha S, Shirkot CK. Purification and characterization of cellulase-free low molecular weight endo $\beta-1,4$ xylanase from an alkalophilic Cellulosimicrobium cellulans CKMX1 isolated from mushroom compost. World J Microbiol Biotechnol. 2014; 30: 2597-2608.
Walia A, Mehta P, Guleria S, Shirkot CK. Improvement for enhanced xylanase production by Cellulosimicrobium cellulans CKMX1 using Central Composite Design of Response Surface Methodology. 3Biotech. 2015; DOI: 10.1007/s13205015-0309-2.

Walia A, Mehta P, Guleria S, Shirkot CK. Modification in the properties of paper by using cellulase-free xylanase produced from alkalophilic Cellulosimicrobium cellulans CKMX1 in biobleaching of wheat straw pulp. Can J Microbiol. 2015; DOI: 10.1139/cjm-2015-0178.

Wong KKY, Tan LUL, Saddler JN. Multiplicity of $\beta$ 1,4 xylanase in microorganisms: functions and applications. Microbiol Rev. 1988; 52: 305-317.

Zhao Y, Meng K, Luo H, Yang P, Shi P, Huang H, et al. Cloning, expression, and characterization of a new xylanase from alkalophilic Paenibacillus sp. 12-11. J Microbiol Biotechnol. 2011; 21: 861-868. 